\title{
Britain's Prevent Strategy: Always Changing, Always the Same?
}

\author{
Paul Thomas
}

\begin{abstract}
This chapter analyses Prevent's development since its introduction in 2006, alongside discussion of its controversies. It considers both Prevent's changing content and priorities over its distinct phases and its significant controversies that have endured despite such changes. Critics argue that Prevent disproportionately targets British Muslims as a 'suspect community', as well as securitising society and undermining community cohesion. These critiques have persisted despite the very significant shift of focus from community-based engagement work in the 'Prevent 1' phase to the 'Prevent 2' phase and Prevent Duty concern with identifying individual vulnerability to radicalisation. Here, this chapter considers how we can understand both Prevent's changes and the controversies around the 2015 introduction of the 'Prevent Duty', alongside their implications for front-line educational practitioners and institutions.
\end{abstract}

Keywords Prevent $\bullet$ Policy $\bullet$ Counter-terrorism $\bullet$ Education $\bullet$ Muslims

\section{P. Thomas $(\bowtie)$}

Huddersfield Centre for Research in Education and Society (HudCRES), University of Huddersfield, Huddersfield, UK

e-mail: d.p.thomas@hud.ac.uk 


\section{Introduction}

The Prevent Duty's introduction in 2015 represented a significant new development within the UK's Prevent counter-terrorism strategy, but there was nothing new about the tone and content of the public controversy that accompanied it. The Prevent strategy has altered and developed significantly over its policy lifetime, but the sharp public critiques of Prevent as stigmatising British Muslims, threatening free speech and securitising British society have remained constant. For many critics, Prevent always has, and always will be, really about Muslims and the perceived threat to broader British society from strands of domestic Muslim communities. Other critics identify a shifting, but enduring, broader securitisation of society and an inherent threat to free speech within Prevent. These already-existing critiques have all been applied since 2015 to the Prevent Duty's introduction across the education, health and social welfare sections of Britain's public services, and they raise an analytical dilemma. Do such critiques represent the reality of the Prevent Duty's implementation, or are they really claims about what Prevent was, rather than what it is today?

I have argued elsewhere (Thomas, 2017) that we can identify two distinct phases of Britain's Prevent Strategy, with a significant third phase emerging with the Prevent Duty's introduction. During 'Prevent 1', 2006-2011, the main focus of Prevent activity was community-based work with young Muslims, through Department for Communities and Local Government (DCLG) funding. The 'Prevent 2' phase was initiated by the new Coalition government's 2011 Prevent Review and was very different in content and focus. That review removed the DCLG from Prevent involvement and largely ended Prevent's community-based element. Instead, it confirmed an enhanced Prevent focus on individuals 'at risk' of, or vulnerable to, 'radicalisation'. The 2015 introduction of the Prevent Duty confirmed and significantly accelerated this 'Prevent 2' trajectory.

This chapter does two things. First, it traces the development of the Prevent strategy from its first implementation in 2006/7. In doing so, it explores both the continuities and changes within Prevent over this 
period and shows how the Prevent Duty can be understood as an innovation that, in effect, consolidated a series of prior policy developments. Second, it outlines key criticisms of Prevent and how these have, or have not, evolved in response to developments in Prevent. These three phases of the Prevent strategy are explored, in each case outlining both the phase's key content and priorities and identifying the associated controversies and criticisms.

\section{'Prevent 1' and Its Criticisms}

Britain's Prevent strategy is part of the broader UK CONTEST national counter-terrorism strategy, which has gone through several iterations (HMG, 2018) since its inception in 2003. CONTEST is built around four strands, the so-called 4 P's, of Prevent, Pursue, Protect and Prepare, with Prevent undoubtedly the most controversial. This post-9/11 development of a preventative arm within national counter-terrorism strategies has been a feature internationally, with many developed and developing countries initiating such programmes. These national strategies have variously been called 'Preventing Violent Extremism (PVE)' or 'Countering Violent Extremism (CVE)', leading to many international analysts using a hybrid 'P/CVE' description (Rosand, Winterbotham, Jones, \& Praxi-Tabuchi, 2018).

Britain originally utilised the PVE title for the 'Prevent 1' local programme and has subsequently reduced this to 'Prevent'. Britain was an early adopter of such a PVE policy approach and has resultantly been much-studied internationally, with this scrutiny being aided by the fact that Britain's comparatively centralised government gives an apparent national coherence to Prevent. Whilst there is significant international dialogue over P/CVE policies through bodies such as the European Union, the United Nations and the so-called five eyes network (UK, USA, Australia, Canada and New Zealand), Prevent is, and has been, a nationally determined policy. Whilst most developed nations have policies aimed at identifying and supporting individuals vulnerable to radicalisation in ways similar to Prevent's Channel system, Prevent is internationally distinctive in enforcing this through a legal duty on 
educational professionals, and also, in the 'Prevent 2' and 'Prevent Duty' phases, in its down-playing of broader, community-based resiliencebuilding work.

Originally envisaged as an international-focussed programme, Prevent emerged as a domestic programme in the wake of the 7/7 London bombings of July 2005. Its very emergence was contested, with local government and civil society organisations arguing for broader policy approaches (Thomas, 2012). This 'Prevent 1' phase, initiated by the Labour government, was explicitly only about Muslim communities, with the DCLG PVE funding administered — at very short notice—on the basis of local Muslim populations. Here, the resulting activity focussed overwhelmingly on young Muslims, largely through youth and community work and with little or no concern with formal education (Phillips, Tse, \& Johnson, 2011). Funding was also utilised to strengthen Muslim civil society, such as after-school religious education bodies. In some areas, local government deployed the funding itself, but in other areas they largely passed the funding on to Muslim organisations, leading to a very significant inflow of funding to these groups from an explicitly counterterrorism policy fund. This was mirrored by national efforts to develop new representative structures for Muslim women and young people, and even government promotion of more 'moderate' forms of Islamic religious interpretation. Alongside this came 300 new, dedicated Police posts and a significant role for Police Prevent staff in community engagement and in the broader development of local PVE strategies.

This approach was controversial from inception, and the critiques that developed during 'Prevent 1' continue to significantly shape current public perceptions of Prevent (see Chaps. 5, 6, 7, and 8), despite the substantially altered content and priorities of 'Prevent 2' and the subsequent Duty. The first of these was that Prevent stigmatises Muslims, seeing them as an undifferentiated 'suspect community', a term first applied to Irish-origin communities resident in Britain at the time of the Northern Ireland troubles (Hillyard, 1993). Prevent's explicitly Muslim-only focus, and the sheer scale of it - government evaluation of the first year of PVE funding boasted of engaging with over 50,000 young Muslims (Thomas, 2012) — made this analysis hard to refute. Essentially, 'Prevent 1' represented a community development intervention within Muslim 
communities on a significant scale and on an explicitly counter-terrorism basis. Here, Prevent's monocultural focus clearly contradicted the community cohesion policies, developed following the 2001 riots in northern England, that sought to promote cross-community dialogue and common identities (Thomas, 2011). It focussed only on Islamist terrorism at a time when far-right organisations were both winning local elections and provoking localised racial tensions. This concern of stigmatisation was evident in the House of Commons Communities and Local Government Select Committee Inquiry in to Prevent in 2009-2010, with their report (House of Commons, 2010) urging a re-thinking of Prevent and a much stronger role for cohesion-based work.

Alongside this was a concern that Prevent was securitising society through the role of the Police within it. The new Police 'Prevent Engagement Officer' roles facilitated a large-scale involvement with Muslim communities around the issue of extremism, with some officers working directly with young people and adult community members in roles normally played by youth and community workers (Thomas, 2010). Allegations that such Prevent Police, and staff from the Intelligence and Security Service (MI5), were pressurising front-line youth workers for information on potentially extremist young people were central to Arun Kundnani's 'Spooked' report (2009), which received very considerable media coverage. Beyond dispute is that the Police gradually became more dominant in the local management and direction of Prevent (Bahadur Lamb, 2012). Central to this concern around securitisation was that even prior to the development of Channel and the Prevent Duty, individuals were being surveilled for extremist words and beliefs, so threatening free speech and civil liberties (Kundnani, 2009).

Some key concepts can be useful to help us describe and understand the Prevent strategy's journey. One is 'responsibilisation' (Thomas, 2017), with Prevent making different sectors of society responsible for ensuring that terrorism is prevented over time. Within 'Prevent 1', it was Muslim communities that were responsibilised as 'moral agents' of terrorism prevention (Choudhury \& Fenwick, 2011). This approach assumed that the Al-Qaida-inspired attacks in London on July 7, 2005, and other foiled plots could be directly linked to the faith community that attackers claimed to speak on behalf of, and that community and religious bodies 
could be mobilised to protect against the type of extremism that supposedly led to such acts. Basia Spalek (2013) identifies this 'Prevent 1' approach of trusting and funding Muslim communities as a new departure for counter-terrorism policies. For some (see Abbas, 2018), this was about Prevent encouraging Muslim communities to spy on each other, but McGhee (2010) saw it instead as an approach that attempted to limit stigmatisation by the state working in partnership with communities, rather than 'doing' terrorism prevention to them. Arguably, this was also recognition of the state's limited understanding of and ability to oppose extremism within Muslim communities.

It is certainly true that some Muslim communities refused Prevent funding and rejected policy engagement from the start, but other Muslim communities accepted the funding, using it to develop community organisation and resilience against extremist influences (Lowndes \& Thorp, 2010). The devolved funding approach of 'Prevent 1' actively encouraged this, meaning that different areas had different experiences of and views on Prevent. O’Toole, Meer, DeHanas, Jones and Modood (2016) drew on empirical research amongst British Muslim communities to suggest that Prevent implementation was a scene of 'contested practice', with local Prevent involvement enabling many Muslim communities to both strengthen civil society and play a stronger role in local government governance. Here, many Prevent critics were Muslim, but many 'Prevent 1' advocates and actors were also Muslims.

\section{'Prevent 2' and Its Criticisms}

Whilst significantly delayed by strong disagreements about Prevent within the new Conservative-Liberal Democrat Coalition government (Warsi, 2017), the 2011 Prevent Review (HMG, 2011) marked a major turning point for Prevent. Firstly, it officially expanded Prevent's focus to all forms of terrorism (although Prevent does not cover Northern Ireland and its distinct terrorist threats, hence it being a British, rather than UK-wide, policy). Secondly, it expanded Prevent's concern from 'violent extremism' to a broader 'extremism', introducing the concept (and list) of 'fundamental British values' that has subsequently been foregrounded 
within formal education. For some (see Miah, 2017), this latter expansion is highly significant in that it arguably deepens and widens policy concern with problematic, 'un-British' attitudes and behaviours within Muslim communities. It is questionable, though, as to what tangible difference this expansion of concern has really made to Prevent's priorities and operations. Here, Prevent activity is, by definition, focussed on people and behaviours not yet linked to tangible terrorist planning; otherwise, it would be a 'Pursue' policing concern. P/CVE activity could be seen as always being about a broader 'extremism' that might move towards violent intentions and plans, if not diverted.

The most tangible change, which marked the effective end of 'Prevent 1 ' and the commencement of a new phase, was the removal of DCLG from involvement in the programme and the (virtual) ending of Prevent funding for community-based group resilience-building activity. This was justified as a response to the House of Commons (2010) Select Committee Inquiry report, so supposedly ensuring that there was no damage to (separate) community cohesion policy work:

The Prevent programme we inherited from the last government was flawed. It confused the delivery of Government policy to promote integration with Government policy to prevent terrorism. (HMG, 2011, p. 1)

In reality, though, this shift represented a distinctly different understanding of the role and purpose of Prevent, and mis-characterised the actual conclusions of the Select Committee Inquiry. The Select Committee Inquiry evidence hearings (House of Commons, 2010) saw national Police leaders questioning what the point of the community-based Prevent activity was; they described it as simply 'community cohesion' work. Of course, it wasn't cohesion work as it had a monocultural focus. Underpinning this Police questioning was distrust in the efficacy of Prevent 1's community-based work that aimed to build individual and group resilience against extremism well before individual tangible involvements in extremism were developing. The Select Committee findings actually supported such work, but argued that it should be done on a (cross) community cohesion basis, partly because hostility to 'other' communities is a key driver of extremism and terrorism. Instead, the new 
government chose to largely end community-based Prevent work, with only a limited programme of local activities in 'Prevent priority' areas and those strongly controlled from London by the Home Office. This substantial downsizing of Prevent work in communities also enabled an austerity-focussed government to significantly reduce the overall Prevent budget. They also completely ended national funding for community cohesion work, leaving local government to continue such work with their own (rapidly reducing) resources (Thomas, 2014).

Instead, this new 'Prevent 2' phase was primarily about identifying and diverting individuals vulnerable to radicalisation through the Channel anti-radicalisation mentoring and counselling system. Channel had been developing on a pilot basis in the years prior to 2011 (Thornton \& Bouhana, 2017), and it was now foregrounded as the key element of Prevent. Central to this approach of identifying vulnerability is the concept of 'radicalisation', a term that has developed in the post-9/11 era of domestic terrorism to characterise people who move towards terrorist involvements (Coolsaet, 2016). Whilst the engagement of individuals in terrorism is a reality - as the domestic terror attacks and foiled plots in both the UK and across other Western countries show (Nesser, 2015) there is little agreement over why people make this journey. Exhaustive academic analysis has clearly demonstrated that there is no definable set of indicators or social and economic circumstances, no identifiable 'conveyer belt' process (Kundnani, 2012), that can predict who will move towards terrorism, when and why. This makes the concept of 'radicalisation' highly problematic, yet the key focus of 'Prevent 2' was to develop systems of identifying and intervening with individuals apparently at risk of radicalising.

This intervention was to come via the nationally designed but locally led 'Channel' system. Here, individuals identified as potentially vulnerable to radicalisation are referred by organisations such as schools or health bodies to a multi-agency Channel panel within their local authority area, where their individual case is considered. Those judged to be at genuine risk are offered an anti-radicalisation intervention package, often mentoring by a government-approved 'Intervention Provider' (IP). Many IPs are ex-extremists or people with what are considered relevant theological or political experience or expertise. Initially, local Channel panels were led 
by Prevent Police staff, but there has been a move towards civilianising Channel under local authority leadership through the 'Operation Dovetail' pilot process (Thornton \& Bouhana, 2017).

How to go about identifying individuals vulnerable to radicalisation and what tools and measures to use is an international challenge (Knudsen, 2020). Various countries have devised, and shared, radicalisation assessment tools, such as the Canadian-origin VERA and VERA2. Britain developed the 'ERG 22+' assessment tool, based on analysis of the pathways towards violence of convicted terrorists, and it has led to the 'Vulnerability Assessment Framework' (VAF), which has underpinned the Channel system. Both these British assessment tools have come under significant criticism, which has focussed both on the unreliability of reported pathways from convicted terrorists and on the apparent policy stretching of such insights to use in identifying people who have not yet planned terrorist violence. Certainly, if the ERG 22+ indicators are taken at face value, items like 'a need for identity, meaning and belonging' seem to describe virtually any adolescent. However, the argument in support of all such assessment tools is that they are simply a framework for structured professional judgements by trained professionals.

\section{The Prevent Duty and Its Criticisms}

'Prevent 2' was therefore developing Prevent in a different direction, and doing so both in a down-sized way and with a lower media profile in the period following the 2011 Prevent Review. This makes the new and very significant expansion phase represented by the 2015 Counter-Terrorism and Security Act (CTSA) and its introduction of the Prevent legal duty both unexpected and surprising at first sight. It was, and is, internationally unprecedented in its legal requirement of front-line practitioners and their agencies. Three key events that occurred during the period of 2012-2014 can be identified as motivating the-then-Coalition government's decision to significantly increase Prevent's scale and reach through the introduction of a legal duty'.

Firstly, in 2013, Britain saw the high-profile murder of an off-duty soldier, Fusilier Lee Rigby, by two Islamist militants (both religious 
converts, as a substantial proportion of domestic AQ/ISIS-inspired terrorist have been) already known to the authorities. Significant public impact of this event in Woolwich, south London, came from the filming by bystanders of the attack and its aftermath, and subsequent media use of this footage. This public concern was re-enforced by the concurrent trial of six young Muslims from Birmingham who had planned violent attacks on an English Defence League rally held in Dewsbury, West Yorkshire, in 2012 (BBC News, 2013), prompting fears that Islamist and far-right extremist were mutually radicalising each other. At the same time, there was also growing evidence of a significant number of young Britons attempting to travel to Syria to join ISIS, which had recently taken by force the large geographical area of northern Syria and western Iraq, and declared a 'caliphate'. These events all highlighted questions around the effectiveness of Prevent, and the fact that Prevent's scale and activities had been significantly reduced in the wake of the 2011 review. Unsurprisingly, following Lee Rigby's murder former Labour ministers closely connected to 'Prevent 1', such as Hazel Blears, criticised the withdrawal of local Prevent funding and direction under 'Prevent 2' (Boffey \& Doward, 2013).

Then-Prime Minster David Cameron's response was a 'Task Force on Tackling Radicalisation and Extremism' (HMG, 2013). The resulting report suggested that some local authorities 'are not taking the problem seriously' (ibid: 4) and indicated that it would make Prevent delivery a legal requirement in certain priority areas. It also foregrounded the role of schools, stating that all schools should expect Ofsted inspections to focus clearly on their anti-extremism measures and particularly on their implementation of 'fundamental British values'. Indeed, some were downgraded by Ofsted on this basis in 2014-2015, highlighting the extent to which the introduction of the Prevent Duty in July 2015 was only confirming and deepening an already-existing reality of the need for educational institutions to comply with Prevent.

The Task Force report concluded by saying that further measures would be kept under review. The justification for such further measures was provided by the so-called Trojan Horse affair. This related to a number of state schools with mainly Muslim pupils in Birmingham (Miah, 2017). An anonymous letter claiming 'extremism' in these schools 
prompted the Education Secretary, Michael Gove, to investigate through an inquiry led by a former counter-terrorism Police chief, Michael Clarke. Whilst the resulting report found no evidence of support for violent extremism, this government approach framed an issue of faith's role within local state schools (and their significant improvements in attainment) as overtly one of extremism and implicitly also of a terrorist threat. This intervention was consistent with the 'values-driven' approach to Prevent that Gove had championed in the 2011 Prevent Review process - significantly contributing to Baroness Warsi's resignation from the government (Warsi, 2017) — and which reflected his suspicion of broader attitudes and dispositions amongst Muslim communities generally (see Gove, 2006). This contrasted with Prevent 1's more 'means-driven' pragmatism over community participation (Birt, 2009). This government interpretation of the 'Trojan Horse' affair also ensured that it would indeed toughen its approach to the role within Prevent of formal education, which it did by placing a legal duty to implement the Prevent strategy on all state education, social welfare and health professionals and their institutions nationally through the 2015 CTSA.

This legal duty is internationally unprecedented in relation to counterterrorism, although a similar duty has been placed on Australian educators to report the sexual exploitation of students (Falkiner, Thomson, \& Day, 2017). It is clear that educators and other state professionals have now been responsibilised (Thomas, 2017) for preventing radicalisation towards violent extremism under the CTSA's ramping up of 'Prevent 2', supplanting the focus of responsibilisation on Muslim communities under 'Prevent 1'. The scale of this Duty is obviously significant, with several hundred thousand educators, from early years settings to further education colleges, having received Prevent training, and possibly as many as one and a half million public servants in total, given the scale of the National Health Service.

Implementing this Duty also raises an issue that has dogged Prevent throughout its history-the partial and varied nature of the (funded) policy implementation structures. Here, a number of local authority areas have been designated as 'Prevent priority areas' and have received Home Office funding for full-time Prevent coordinators (and, in recent years, also for education officers to support implementation within the 
education sector). The number of 'priority areas' during the 'Prevent 1' phase was very significantly reduced by the 2011 Prevent Review. It has subsequently grown somewhat, but it remains a reality that many local government areas are not priority areas and so do not have funding to support full-time Prevent staff, yet are legally required to ensure that all the schools and social service organisations within their area are correctly implementing Prevent. This complex contextual reality should be borne in mind as this chapter considers below the key critiques, contestations and issues which accompanied the implementation of the Prevent Duty, particularly in the educational sector.

The first, and certainly the most prominent criticism of the Prevent Duty's implementation, was whether it had simply re-doubled the targeting and stigmatisation of young Muslims that was inherent to 'Prevent 1'. Here, the suggestion was that while the Prevent Duty is theoretically about all forms of extremism, Prevent is still really still about Muslims (see the review of educationally focussed literature within Jerome, Elwick, \& Kazim, 2019). Certainly, the number of Prevent referrals of young people to Channel grew by over $75 \%$ in the year following the Duty's implementation, with those from the educational sector, particularly schools and colleges, more than doubling (Open Society Foundation Justice Initiative (OSFJI), 2016). Young Muslims were, and are, disproportionately represented within these figures.

A number of high-profile, apparently deeply inappropriate, referrals of young Muslims were featured in the media in the months following the Duty's introduction, not all of them factually accurate. These included the so-called terrorist house investigation in Blackburn (which was actually not a counter-terrorism case), and a case in Luton that saw a fouryear-old girl reported to Prevent for mispronouncing 'cucumber' as 'cooker bomb'. Such early cases reinforced public perceptions, which first developed in the 'Prevent 1' phase and which did not weaken during 'Prevent 2', of Prevent as being an Islamophobic policy that undermines the human rights and civil liberties of young Muslims (see OSFJI, 2016). The reality of the significant over-representation of young Muslims within Prevent referrals in relation to their proportion of the school and college population (see below) has been highlighted by greater government transparency, post-2015, around Prevent operations, with detailed 
annual statistic bulletins of Channel referrals and what happens to them (Home Office, 2019).

The meaning of this Muslim over-representation is significantly contested. For some, this is prima facie evidence of the continued 'suspect community' logic of Prevent, but for others it represents the past reality of the domestic terrorist threat and of the very considerable travel (or attempted travel) to Syria by British Muslims. Certainly, the numbers of people now receiving actual Channel mentoring support for right-wing extremism are very similar to those from ISIS-inspired extremism referrals, a picture which emboldened the Conservative government to accept an Independent Review of Prevent, initiated in 2019. However, the total number of Muslims referred does represent a significant overrepresentation in relation to their place both in Britain's school and college student population, and in the general population. The higher 'no further action', attrition rate for young Muslims within Prevent referrals also raises the issue of whether many of these represent inappropriate professional referrals on the basis of a (mis-)reading of Muslim dress, belief or practice as an indicator of extremism. Is the operation of the Prevent Duty within education leading to further stigmatisation of Muslim students?

One of the factors driving criticism of Prevent Duty operations is the general high attrition rate or Channel referrals, with a very significant proportion leading either to no further action or to other forms of intervention unconnected to issues of extremism. For some critics, this attrition rate in itself demonstrates the generic ineffectiveness of the Prevent strategy, but it's not clear whether such an attrition rate is inconsistent with attrition rates for reporting over other aspects of safeguarding within education. The government framing of Prevent as safeguarding is central to the Duty's operation (see Chaps. 3, 5, 6, 7 and 8), but it is also contested. This contestation has come particularly from the social welfare and health sectors. For social work theorists, Prevent has misappropriated the language of child protection and safeguarding work with vulnerable children and adults, in the cause of counter-terrorism (Coppock \& McGovern, 2014). In particular, they argue that safeguarding has been, and should be, about protecting the needs and interest of these vulnerable individuals, but safeguarding in the name of Prevent is actually 
protecting wider society from these risky individuals. This emphasises the need for more empirical research around how the 'Prevent-as-safeguarding' frame (Busher, Choudhury, \& Thomas, 2019) has been understood and practised within education. Research in adult mental health settings has suggested that professionals are resistant to Prevent reporting over-riding a duty of confidentiality to clients (Heath-Kelly \& Strausz, 2019), but whether patient confidentiality is ever truly absolute is contested. Do educational professionals accept the 'Prevent-as-safeguarding' frame?

Closely connected to these critiques of the Prevent-as-safeguarding frame have been allegations that the introduction of the Prevent Duty represents a securitisation of education, as well as of health and welfare, with educational professionals asked to play policing roles. For supporters of the Prevent Duty, its implementation is genuinely consistent with the focus and operation of wider, pre-existing safeguarding approaches within the education sector. Critics, meanwhile, see it as representing a disjuncture in the systems and assumptions that educationalists utilise and in the way that agencies such as the Police interact with educational institutions. If empirical evidence from educational settings suggests the former interpretation, then to what extent is the Prevent Duty implementation actually a 'securitisation' of education?

An issue for all professionals covered by the Prevent Duty is what they are actually being asked to spot and report-the indicators or warning signs of radicalisation that professionals should be aware of and look for. Discussions above highlighted the problematic concept of 'radicalisation' and the international academic and policy consensus that there is not one clear pathway towards terrorism. However, we know that people do make that journey, and many of the people involved in plots of the last decade, and particularly those travelling to Syria, have been young people who were in, or had only recently left, schools and further education. Both that reality and the Prevent Duty to spot and report any individual at risk raise the issue of how clear individual educators feel they are about what they should look for and what level of concern justifies an external Channel referral. Here, there has been a need for more empirical evidence around who delivers Prevent training, their qualifications and credibility to do so, and what sort of ongoing support is available for educational institutions as they develop their approach to Prevent implementation. 
What does empirical evidence tell us about the quality, clarity and helpfulness of training for professionals in relation to the role mandated by the Prevent Duty?

Throughout the changing focus of Prevent, there has been a concern with the clarity and confidence of the front-line educational professionals being asked to implement Prevent. In 'Prevent 1', there was no policy focus on training or skills development for the youth and community workers at the forefront of Prevent (Thomas, 2012). The implication of this community-based approach was that youth workers would utilise opportunities to develop projects around citizenship and political education that could both address youth grievances and support resilience against extremism, yet there was no Prevent focus on professional competence or confidence. This echoed the failings of previous anti-racism educational policy initiatives, which neglected the crucial issue of practitioners lacking the confidence to successfully facilitate discussion of 'difficult issues' (Thomas, 2009). Under the Prevent Duty, there are clearly two distinct challenges for front-line educators. One is the issue raised above, the safeguarding competence and confidence around spotting relevant signs of 'risk of radicalisation', and knowing what to do about it. The other is one of pedagogical confidence, how educators successfully implement 'fundamental British values' within the curriculum in a way that bolsters students support for common values and which scaffolds resilience against extremist messages - something that may well entail 'difficult conversations' (Thomas, 2016) —as well as being consistent with wider responsibilities to promote equality and cohesion. Here, the 'Prevent 1' concerns of youth and community workers about their confidence and clarity to do such pedagogical work, and the availability of good training and resources to support it, are now challenges for formal educational practitioners within early years, schools and colleges in the Prevent Duty phase. Do educational practitioners feel confident in their ability to fulfil the Prevent Duty?

A final major criticism of the Prevent Duty was that it would be likely to have a 'chilling effect' on the speech and behaviour of students, and of Muslim students in particular, who perceive themselves to be a target of this measure and fear that they will be referred to Prevent. If this is true, it would support claims that Prevent is curtailing the human rights and 
particularly the right to free speech, of Muslim students (OSFJI, 2016). It would also make Prevent counter-productive on its own terms, as Prevent cannot succeed without community members being willing to share concerns and challenge the extremism of others within day-to-day life. There is certainly evidence from the Higher Education (HE) sector (Scott-Baumann, 2018) that Muslim students perceive themselves to be under Prevent surveillance, although other studies of Prevent Duty implementation within higher education suggest something more akin to a form of 'tick box compliance', rather than more significant changes in practice (McGlynn \& McDaid, 2019). Indeed, the Prevent Duty provisions for $\mathrm{HE}$ were amended after legal challenge to reflect the equal legal responsibility to uphold free speech. A highly relevant context for this concern is the very significant anti-Prevent campaigning by civil society groups (Thomas, 2017) and the National Union of Students, based on claims that Prevent is indeed surveillance of Muslims. Here, the sociological theorem that if enough people believe something to be true, it is real in its consequences, has considerable relevance for the public understanding of Prevent and its legal duty, and it certainly makes empirical analysis of any 'chilling effect' amongst students in schools and colleges more complicated. Has the Prevent Duty led to a 'chilling effect' amongst Muslim students, and if so, how can we judge this?

\section{Closing Thoughts}

This chapter has charted the development of the Prevent strategy from its introduction in 2006/7 to the introduction of the Prevent Duty in 2015. In doing so, it has highlighted the very significant changes in Prevent's content and priorities from the 'Prevent 1' phase of community development work with British Muslims to the 'Prevent 2' focus on systems for identifying, reporting and intervening with individuals perceived to be 'at risk' of radicalisation, which was expanded by the Prevent Duty. This shift from 'Prevent 1' to 'Prevent 2' also involved a shift from a primary Prevent concern with youth and community workers to a concern with the educational professionals working in early years, school and further 
education settings, a shift which the enhanced Prevent Duty phase confirmed and deepened.

This chapter highlighted the significant public controversies over Prevent in its original, 'Prevent 1' form, particularly its overt focus on Muslims only, and the resulting contradiction with policies of community cohesion, and the role of the Police in community engagement with young people. The argument I make in this chapter is that those original 'Prevent 1' controversies have significantly shaped public perceptions and criticisms of the very different content and focus of 'Prevent 2' and its post-2015 phase of the implementation of the Prevent Duty.

Specifically, this chapter has highlighted how the Prevent Duty's introduction elicited a number of key criticisms that built on those prior objections to Prevent. These included concerns over whether the Duty's new version of Prevent represented an enhanced suspicion and stigmatisation of young Muslims, whether it was consequently 'chilling' the speech and behaviour of Muslim students and whether the Duty represented a significant securitisation of education. Alongside this were questions of whether the government's 'Prevent-as-safeguarding' frame was understood and accepted by educational professionals, whether those professionals felt clear about the role of identifying radicalisation that the Duty requires them to play and whether they generally had the confidence, clarity and skills to implement the safeguarding and pedagogical dimensions of the Prevent Duty.

This in turn raises questions for researchers about the extent to which these vociferous public criticisms reflect the reality of the Prevent Duty's implementation within education, or rather whether they actually represent a form of inertia or 'lag' amongst critics who still understand Prevent as what it was, rather than the significantly modified strategy that it now is. It suggests the possibility that government and the Prevent critics are, in effect, 'talking past each other' in their heated dialogue about justifications for and impacts of Prevent, with educators at the centre of these disputes. Others will reject such a view and argue that Prevent Duty implementation is a damaging reality within education. These are important questions and issues that we need more empirically based investigation of, and the following chapters respond to that challenge. 


\section{References}

Abbas, M. S. (2018). Producing 'internal suspect bodies': Divisive effects of UK counter-terrorism measures on Muslim communities in Leeds and Bradford. British Journal of Sociology, 70(1), 262-281.

Bahadur Lamb, J. (2012). Preventing Violent Extremism: A policing case study of the West Midlands. Policing, 7(1), 88-95.

BBC News. (2013, June 10) English Defence League rally bomb plotters jailed. Retrieved from http://www.bbc.co.uk/news/uk-22841573

Birt, Y. (2009). Promoting virulent envy - Reconsidering the UK's terrorist prevention strategy. Royal United Services Institute (RUSI) Journal, 154(4), 52-58.

Boffey, D. \& Doward, J. (2013, May 25). Woolwich attack: Coalition failing to tackle extremism, says Hazel Blears, The Observer. Retrieved from www.theguardian.com/uk/2013/may/25/woolwich-attack-hazel-blears-attacks-coalition

Busher, J., Choudhury, T., \& Thomas, P. (2019). The enactment of the counterterrorism 'Prevent duty' in British schools and colleges: Beyond reluctant accommodation or straightforward policy acceptance. Critical Studies on Terrorism, 12(3), 440-462.

Choudhury, T., \& Fenwick, H. (2011). The impact of counter-terrorism measures on Muslim communities (Vol. 25, p. 151). London: Human Rights Commission.

Coolsaet, R. (2016). 'All radicalisation is local': The genesis and drawbacks of an elusive concept. Brussels, Belgium: Egmont.

Coppock, V., \& McGovern, M. (2014). Dangerous minds? De-constructing counter-terrorism discourse, radicalisation and the 'psychological vulnerability' of Muslim children and young people in Britain. Children and Society, 28(3), 242-256.

DCLG. (2008). Prevent Pathfinder Fund: Mapping of project activities 2007/08. London: DCLG.

Falkiner, M., Thomson, D., \& Day, A. (2017). Teachers' understanding and practice of mandatory reporting of child maltreatment. Children Australia, 42(1), 38-48.

Gove, M. (2006). Celsius 7/7. London: Weidenfeld and Nicolson.

Heath-Kelly, C., \& Strausz, E. (2019). The banality of counterterrorism 'After, After 9/11'? Perspectives on the Prevent Duty from the UK health care sector. Critical Studies on Terrorism, 12(1), 81-109.

Her Majesty's Government (HMG). (2011). Prevent Strategy. London: The Stationary Office. 
Hillyard, P. (1993). Suspect community: Peoples' experience of the Prevention of Terrorism Acts in Britain. London: Pluto.

HMG. (2013). Tackling extremism in the UK: Report from the prime Minister's task force on tackling radicalisation and extremism. London: HM Government. HMGt. (2018). CONTEST: The United Kingdom's strategy for countering terrorism. London: HMG.

Home Office (2019). Prevent and Channel Factsheet. London: Home Office. Retrieved from https://homeofficemedia.blog.gov.uk/2019/12/19/preventand-channel-factsheet/

House of Commons Communities and Local Government Committee. (2010). Preventing Violent Extremism: Sixth report of session 2009-10. London: The Stationary Office.

Jerome, L., Elwick, A., \& Kazim, R. (2019). The impact of the Prevent Duty on schools: A review of the evidence. British Educational Research Journal, 45(4), 821-837.

Knudsen, R. A. (2020). Measuring radicalisation: Risk assessment conceptualisations and practice in England and Wales. Behavioral Sciences of Terrorism and Political Aggression, 12(1), 37-54.

Kundnani, A. (2009). Spooked: How not to prevent violent extremism. London: Institute of Race Relations.

Kundnani, A. (2012). Radicalisation: The journey of a concept. Race and Class, 54(2), 3-25.

Lowndes, V., \& Thorp, L. (2010). Preventing Violent Extremism - Why local context matters. In R. Eatwell \& M. Goodwin (Eds.), The new extremism in 21st century Britain (pp. 123-141). London: Routledge.

McGhee, D. (2010). Security, citizenship and human rights: Shared values in uncertain times. Basingstoke, UK: Palgrave Macmillan.

McGlynn, C., \& McDaid, S. (2019). Radicalisation and counter-radicalisation in Higher Education. Bingley: Emerald.

Miah, S. (2017). Muslims, schooling and security: Trojan horse, Prevent and racial politics. Basingstoke, UK: Palgrave Pivot.

Nesser, P. (2015). Islamist terrorism in Europe: A history. London: Hurst.

O’Toole, T., Meer, N., DeHanas, D., Jones, S., \& Modood, T. (2016). Governing through Prevent? Regulation and contested practice in state-Muslim engagement. Sociology, 50(1), 160-177.

Open Society Foundation Justice Initiative (OSFJI). (2016). Eroding trust: The UK's Prevent counter-extremism strategy in health and education. New York: OSFJI. 
Phillips, C., Tse, D., \& Johnson, F. (2011). Community cohesion and prevent: How have schools responded? London: Department for Education.

Rosand, E., Winterbotham, E., Jones, M., \& Praxi-Tabuchi, F. (2018). A roadmap to progress: The state of the global P/CVE agenda. London: RUSI.

Scott-Baumann, A. (2018). Trust within reason: How to trump the hermeneutics of suspicion on campus. In P. Morey, A. Soliman, \& A. Yaqin (Eds.), Muslims, trust and multiculturalism: New directions (pp. 51-72). Basingstoke, UK: Palgrave Macmillan.

Spalek, B. (2013). Terror crime prevention with communities. London: Bloomsbury Academic.

Thomas, P. (2009). Between two stools? The Government's Preventing Violent Extremism agenda. The Political Quarterly, 80(2), 482-492.

Thomas, P. (2010). Failed and friendless: The UK's 'Preventing Violent Extremism' programme'. The British Journal of Politics \& International Relations, 12(3), 442-458.

Thomas, P. (2011). Youth, multiculturalism and community cohesion. Basingstoke, UK: Palgrave Macmillan.

Thomas, P. (2012). Responding to the threat of violent extremism - Failing to Prevent. London: Bloomsbury Academic.

Thomas, P. (2014). Divorced but still co-habiting? Britain's Prevent/community cohesion tensions. British Politics, 9(4), 472-493.

Thomas, P. (2016). Youth, terrorism and education: Britain's Prevent programme. International Journal of Lifelong Education, 35(2), 171-187.

Thomas, P. (2017). Changing experiences of responsibilisation and contestation within counter-terrorism policies: The British Prevent experience. Policy and Politics, 45(3), 305-322.

Thornton, A., \& Bouhana, N. (2017). Preventing radicalization in the UK: Expanding the knowledge-base on the Channel programme. Policing, 13(3), 331-344.

Warsi, S. (2017). The enemy within: A tale of Muslim Britain. London: Allen Lane. 
Open Access This chapter is licensed under the terms of the Creative Commons Attribution 4.0 International License (http://creativecommons.org/licenses/ by/4.0/), which permits use, sharing, adaptation, distribution and reproduction in any medium or format, as long as you give appropriate credit to the original author(s) and the source, provide a link to the Creative Commons licence and indicate if changes were made.

The images or other third party material in this chapter are included in the chapter's Creative Commons licence, unless indicated otherwise in a credit line to the material. If material is not included in the chapter's Creative Commons licence and your intended use is not permitted by statutory regulation or exceeds the permitted use, you will need to obtain permission directly from the copyright holder.

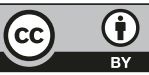

